\title{
RELATIONSHIP BETWEEN LIGNIN CONTENT AND QUALITY OF Pinus taeda SEEDLINGS ${ }^{1}$
}

\begin{abstract}
João Alexandre Lopes Dranski², Ubirajara Contro Malavasi ${ }^{3}$ e Marlene de Matos Malavasi ${ }^{3}$
ABSTRACT - The essay objective was to correlate lignin content resulting from tigmomorphogenesis induced by stem swaying with survival and post-planting growth of $P$. taeda seedlings. Seedlings were subjected to daily frequencies $(0,5,10,20$ and 40 movements $)$ of stem swaying for 60 days. By the end of the treatments, we determined lignin content of below and aboveground seedling tissues. Four replicates per treatment were planted in a area cultivated with pines. Ninety days after planting, survival and increments of seedling height, stem diameter and stem volume were quantified. Application of 20 stem swayings increased lignin in both below and aboveground plant tissues. Outplanted seedling survival was reduced with 40 stem swayings while growth increments were increased with both 10 and 20 stem swayings. Lignin content from belowground plant tissues was positively correlated with outplanted seedling survival while lignin from aboveground tissues correlated with height and stem volume increments. P. taeda seedlings with higher lignin content have higher survival chances after planting.
\end{abstract}

Keywords: Thigmomorphogenesis; Hardening; Stem swaying.

\section{RELAÇÃO ENTRE TEOR DE LIGNINA E QUALIDADE DE MUDAS DE Pinus taeda}

\begin{abstract}
RESUMO - O ensaio objetivou correlacionar o teor de lignina resultante da tigmomorfogênese induzida porflexões caulinares com a sobrevivência e o crescimento pós-plantio em mudas de P. taeda. As mudas foram submetidas a cinco frequências de flexões caulinares diárias $(0,5,10,20$ e 40 flexões) com o auxilio de um aparato mecânico por 60 dias. Ao final, determinou-se o teor de lignina nos tecidos radiculares e aéreos. Quatro repetições por tratamento foram plantadas em uma área de monocultivo de Pinus. Noventa dias após o plantio, quantificou-se as taxas de sobrevivência e de crescimento inicial em altura, em diâmetro do coleto, e volume do caule. A aplicação da frequência de 20 flexões induziu a um aumento no teor de lignina nos tecidos radiculares e aéreos. A campo, a sobrevivência das mudas foi reduzida com o tratamento de 40 flexões, enquanto as taxas de crescimento foram aumentadas com a aplicação de 10 ou 20 flexões. $O$ teor de lignina nos tecidos radiculares correlacionou-se positivamente com a sobrevivência a campo da mudas, enquanto o teor nos tecidos aéreos correlacionou-se com os incrementos em altura e no volume do caule. Mudas de P. taeda com maior teor de lignina apresentam maiores chances de sobrevivência pósplantio.
\end{abstract}

Palavras-chave: Tigmomorfogênese; Rustificação; Flexão caulinar.

\footnotetext{
${ }^{1}$ Recebido em 28.03.2014 aceito para publicação em 07.07.2015.

${ }^{2}$ Universidade Estadual do Oeste do Paraná, Programa de Pós-Graduação em Agronomia, Marechal Cândido Rondon, PR

- Brasil.E-mail: <joaodranski@yahoo.com.br>.

${ }^{3}$ Universidade Estadual do Oeste do Paraná, Centro de Ciências Agrárias, Marechal Cândido Rondon, PR - Brasil. E-mail:

<biramalavasi@yahoo.com.br>e < marlenemalavasi@yahoo.com.br>.
} 


\section{INTRODUCTION}

Survival, establishment, management practices and initial growth of forest stands depend in part on the quality of planted seedlings (CLOSE et al., 2005). The initial growth of newly planted is modulated not only by the seedling inherent potential, i.e. vigour, but also by environmental conditions of the planting site that enable the expression of such potential (GROSSNICKLE, 2012).

Seedling quality is related to their genetic makeup, vigour and environmental conditions of the planting site and can be modified by growth regime and planting practices (DAVIS; JACOBS, 2005). The influence of the growth regime in the nursery determines the level of phenotypic and physiological changes resulting from efforts to achieve the ultimate expression of the propagated genotype (DEL CAMPO et al., 2010).

Response of plant growth to mechanical disturbance was coined as thigmomorphogenesis by Jaffe (1973) which causes reduction of primary growth (TELEWSKI; PRUYN, 1998; COUTAND et al., 2010), changes biomechanical properties of wood (CORDERO, 1999) and stimulates biosynthesis and chemical composition of lignin (KERN et al., 2005; HAMANN et al., 2009; SAIDI et al., 2011; RAMOS et al., 2012).

Lignin is considered a macromolecule, with phenylpropanoidic origin, with vital importance in plant support by providing stiffness needed to maintain verticality of the stem (MONTEIRO et al., 2004). After cellulose, lignin is the second most abundant organic component in plants, representing approximately $30 \%$ of assimilable carbon in the biosphere. In cellular development, lignin is the last organic component to be incorporated involving the complex fibril of secondary cell wall (BOERJAN et al., 2003).

Lignin biosynthesis is a complex process involving several enzymes of synthesis reactions and polymerization of three phenylpropanoids: coumaric acid, coniferyl acid and sinapic acid which correspond to $\mathrm{p}$ - hydroxyphenyl (unit H), guaiacyl (unit G) and syringyl propane (unit $S$ ), respectively from the phenylalanine secreted in the cytoplasm and oxidized on the cell wall by the action of peroxidase, phenol oxidase or laccase (MARJAMAA et al., 2009).

The study of lignin from wood plants is aimed at genetic and biotechnological improvement to obtain genotypes with different levels of lignification depending on the use of wood for pulping or charcoal (PETER et al., 2007; PEREIRA et al., 2011; MEDEIROS NETO et al., 2012).

Few studies have been conducted regarding seedling quality which focuses mostly on ecological aspects of entomology, phytopathology and soil nutrient cycling, creating a gap in the forest sector regarding the association between the degree of seedling lignification and seedling field establishment (ROWELL, 2006; PELTIER et al., 2009; PILATE et al., 2012).

The relationship between seedling lignification and field survival is controversial. For example, Voelker et al. (2011) reported that Populus spp hybrids with low lignin content showed high field mortality while Alvarez-Clare and Kitajima (2007) found no correlation between lignin content and seedling survival of eight tropical wood species.

In the literature there are no reports that the application of mechanical disturbances by means of stem swayings could induce an increase of lignin biosynthesis. Given the above, this study aimed to relate lignin content induced by stem swayings with survival and early growth of Pinus taeda L. seedlings.

\section{MATERIALS AND METHODS}

Pinus taeda L. (RNC 04705) seedlings were produced by seeds in the nursery of Sbaraini Agropecuária S.A. Company, located in Cascavel, PR. Sowing took place in October 2010, in $90 \mathrm{~cm}^{3}$ quadratic section plugs filled with commercial substrate $\left(\right.$ Mecplant ${ }^{\mathbb{R}}$ ) accommodated in flat plastic trays with capacity for 192 containers. The fertilizer consisted of $200 \mathrm{~g}$ of controlled release fertilizer (Osmocote ${ }^{\circledR}$ Plus 8 months) of $\mathrm{N}_{2}-\mathrm{P}_{2} \mathrm{O}_{5}-\mathrm{K}_{2} \mathrm{O}$ formulation (15-9-12) mixed in $25 \mathrm{~kg}$ of substrate.

Seedling production lasted for 8 months from sowing. The first four months seedlings were placed in a greenhouse and the remaining exposed to full sun with a reduction in the number of seedlings per tray to half of the initial occupancy. Seedlings were irrigated daily close to saturation of the substrate.

At the end of the growth phase (after six months), when the seedlings had $16.8 \pm 0.40 \mathrm{~cm}$ in height and a stem diameter of $3.40 \pm 0.11 \mathrm{~mm}$, they were transferred to the Biological Control Centre (Centro de Controle Biológico) of the State University of Western Paraná 
(Universidade Estadual do Oeste do Paraná) in Marechal Cândido Rondon. Seedlings remained in the nursery, exposed to full sun during sixty days, which corresponded to the period of treatment application. The average air temperature during that period was $19.29^{\circ} \mathrm{C}$ and the relative humidity was $74.38 \%$ measured by a datalogger.

In order to induce different levels of lignin, five frequencies $(0,5,10,20$ and 40$)$ of stem swaying were applied daily to the seedlings. All seedlings were mechanically swayed by a mechanical device developed by Volkweis et al. (2014) comprised of a horizontal PVC pipe bar $25 \mathrm{~mm}$ in diameter filled with plaster and secured by a metal frame with bearings, which allowed the displacement of the bar on the nursery bench (Figure 1).

Seedling stems were swayed no more than $45^{\circ}$ by the PVC bar which touched the lower third of the crown at $5.0 \mathrm{~cm}$ from the apical bud in a forward/backward motion. Each movement was counted as a single sway. Movements were performed at a rate of $0.10 \mathrm{~m} \mathrm{sec}^{-1}$ once a day at 09:00 am. Treatments began in June 2011 and ended in August 2011, lasting sixty days when seedlings were ready for planting.

Seedlings were outplanted in an area previously managed for Pinus in September 2011 which was uncultivated for two years located in Cascavel, PR with geographical coordinates of $24^{\circ} 59.811^{\prime} \mathrm{S}$ and $53^{\circ}$ $13.826^{\prime} \mathrm{W}$, and altitude of $752 \mathrm{~m}$. The climate of the region according to the Köppen is classified as Humid Subtropical Mesothermal with hot summers (average temperature above $22^{\circ} \mathrm{C}$ ), with tendency of concentrated rainfall, winters with unfrequent frosts (average temperature below $18^{\circ} \mathrm{C}$ ). The soil of the area is classified as rhodic hapludox, clayey (EMBRAPA, 2006) with the chemical attributes listed in Table 1.

Seedlings were planted in a spacing of $3 \mathrm{~m}$ between rows and $2 \mathrm{~m}$ between plants. Planting roles averaged $0.15 \mathrm{~m}$ of radius and $0.40 \mathrm{~m}$ depth and received $100 \mathrm{~g}$ of a controlled release fertilizer (Basacote ${ }^{\circledR}$ Plus 9 months) with a $\mathrm{N}_{2}-\mathrm{P}_{2} \mathrm{O}_{5}-\mathrm{K}_{2} \mathrm{O}$ formulation (16-8-12). There was no previous soil preparation and liming. Cultural practices involved through weed mowing before planting and weed control of a radius of $0.60 \mathrm{~m}$ around seedling ninety days after planting.

At the end of the treatments, lignin concentration was quantified of above and belowground seedling tissues in four replications of ten seedlings each per treatment.

The procedure for lignin extraction for above and belowground seedling tissues used acid detergent (LDA) procedure proposed by Van Soest (1994). Root and shoot biomasses were dried with an air circulating oven
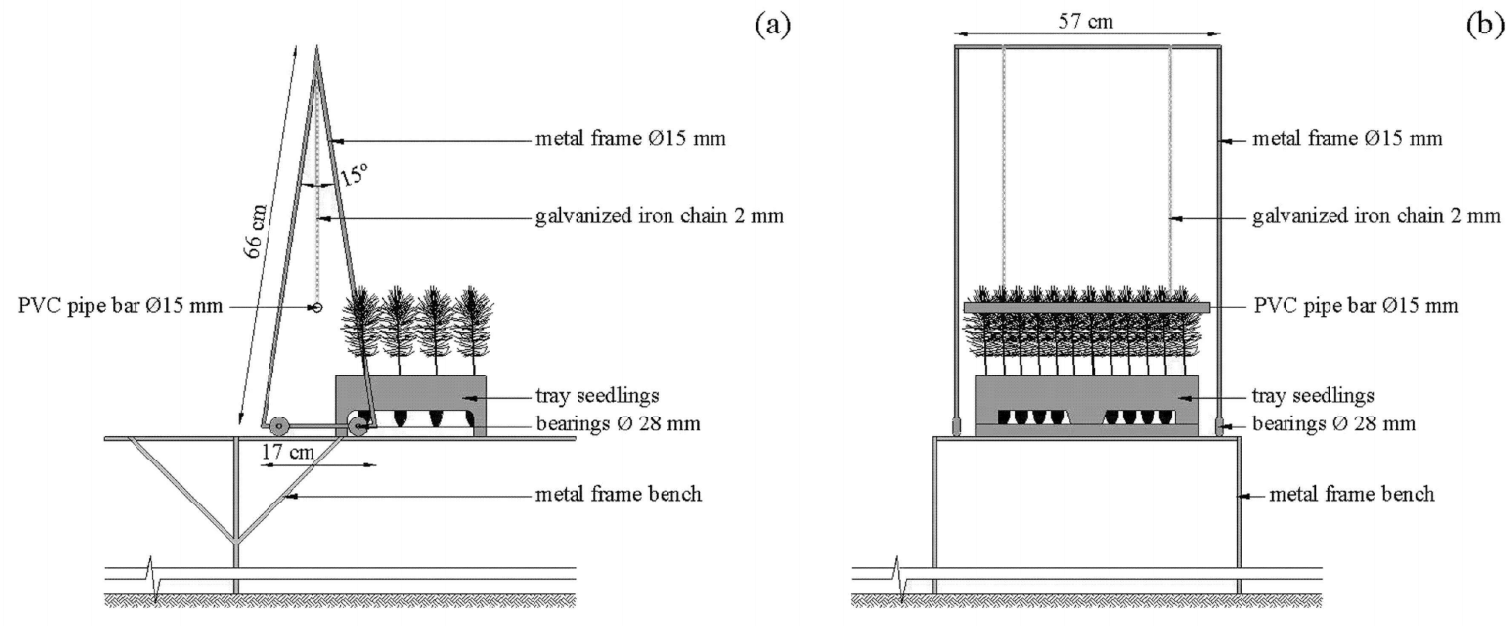

Figure 1 - Graphical representation of the equipment built to submit $P$. taeda seedlings to stem swaying. (a) Side view; (b) Frontal view.

Figura 1 - Representação gráfica do equipamento construído para efetuar as flexões caulinares em mudas de $\boldsymbol{P}$. taeda. (a) Vista lateral; (b) Vista frontal. 
Table 1 - Soil chemical properties of the experimental area.

Tabela 1 - Propriedades químicas do solo da área de implantação do experimento.

\begin{tabular}{|c|c|c|c|c|c|c|c|c|c|c|c|}
\hline \multirow{2}{*}{$\begin{array}{c}\text { Depth } \\
\mathrm{cm}\end{array}$} & \multirow{2}{*}{$\begin{array}{l}\mathrm{OMg} \\
\mathrm{dm}^{-3}\end{array}$} & \multirow{2}{*}{$\begin{array}{c}\text { AP } \mathrm{mg} \\
\mathrm{dm}^{-3}\end{array}$} & \multicolumn{6}{|c|}{ Cation exchange $\left(\mathrm{cmol}_{\mathrm{c}} \mathrm{dm}^{-3}\right)$} & \multirow{2}{*}{$\mathrm{BS} \%$} & \multirow{2}{*}{ ASP \% } & \multirow{2}{*}{$\mathrm{pH} \mathrm{CaCl}{ }_{2}$} \\
\hline & & & $\mathrm{K}^{+}$ & $\mathrm{Mg}^{2+}$ & $\mathrm{Ca}^{2}$ & $\mathrm{Al}^{3+}$ & $\mathrm{H}+\mathrm{Al}$ & $\mathrm{CEC}$ & & & \\
\hline $0-20$ & 20.51 & 6.85 & 0.35 & 1.29 & 2.07 & 0.55 & 6.70 & 10.41 & 35.64 & 12.91 & 4.60 \\
\hline $20-40$ & 12.30 & 0.94 & 0.10 & 0.55 & 0.88 & 0.95 & 7.90 & 9.43 & 16.22 & 38.31 & 3.80 \\
\hline
\end{tabular}

Wherein: (OM) Organic matter; (AP) Available phosphate; (CEC) Cation exchange capacity; (BS) Base saturation percentage; (ASP) Aluminium saturation percentage.

at $60{ }^{\circ} \mathrm{C}$ for 72 hours, grounded in a Willye mill, and passed through a 40 mesh screen. Tissue sample of $0.5 \mathrm{~g}$ were placed in $4 \times 5 \mathrm{~cm}$ nonwoven fabric (TNT) bags made from a polypropylene base with grammage of $100 \mathrm{~g} \mathrm{~m}^{2}$.

Each bag with tissue sample was placed in $1.0 \mathrm{~L}$ plastic bottles with $40 \mathrm{~mL}$ of FDA solution $(20 \mathrm{~g}$ of cetyltrimethyl ammonium bromide, plus $27.4 \mathrm{~mL}$ of concentrated $\mathrm{H}_{2} \mathrm{SO}_{4}$ diluted in $1.0 \mathrm{~L}$ ) and autoclaved at $100{ }^{\circ} \mathrm{C}$ for 20 minutes. Afterwords, each bag was washed in tap water and immersed for 5 minutes in $30 \mathrm{ml}$ of P.A. acetone followed by oven drying at $105^{\circ} \mathrm{C}$ for 8 hours and weighed.

Lignin extraction consisted of immersing the prepared TNT bags with tissue sample in $72 \% \mathrm{H}_{2} \mathrm{SO}_{4}$ for 3 hours followed by water washing and oven drying as above described. After weighing, the TNT bags were placed in porcelain crucibles and subjected to carbonization in oven at $550^{\circ} \mathrm{C}$ for 3 hours. Then, the resulting residue from carbonisation was weighed. The results of the lignin content were obtained by using equation 1 , and expressed in $\mathrm{g} \mathrm{kg}^{-1}$.

$$
\operatorname{Lignin}(\%)=\frac{\left[\left(\text { Res }_{\text {As }}-\text { Res }_{c}\right) *(100 / 2 * M A)\right.}{M A}
$$

In which: $\mathrm{RES}_{\mathrm{AS}}=$ dry biomass resulting from sulfuric acid digestion; $\mathrm{RES}_{\mathrm{C}=}$ dry biomass resulting from carbonisation; MA = initial dry biomass.

Percentage of seedling survival was determined ninety days after planting. Increments in height, stem diameter and stem volume were quantified in four replications of five seedlings per treatment.

Stem volume was calculated using Smalian according to equation 2 (FINGER, 1992). The actual volume consisted of the ratio between the sum of the circular stem areas at cotyledon scar region (inferior) and that measured $2.0 \mathrm{~cm}$ below the terminal bud (top) multiplied by the stem length.

$$
\mathrm{V}=\frac{\mathrm{g}_{\text {inf }}+\mathrm{g}_{\text {sup }}}{2} * \mathrm{C}
$$

In which: $\mathrm{V}=$ stem volume in $\mathrm{cm}^{3} ; \mathrm{g}_{\text {inf }}=$ stem area (at the cotyledon scar, in $\mathrm{cm}^{2}$ ); $\mathrm{g}_{\text {sup }}=$ stem area (at $2.0 \mathrm{~cm}$ below terminal bud, in $\left.\mathrm{cm}^{2}\right) ; \mathrm{C}=$ stem length $(\mathrm{cm})$.

In the nursery, the experiment followed a completely randomized design while in the field it used a randomized block design both with four replications maintaining the identity of the treatments in the composition of the blocks.

The results were submitted to Lilliefors test for normal distribution of residuals and Cochran and Bartlett test for homogeneity of variances followed by analysis of variance. When there was significance by the F test, treatment means were compared by Duncan test at 5\% probability with Sigma Plot 12.0 software (SIGMAPLOT, 2011). Subsequently, the simple and partial correlation coefficients were calculated between lignin content of root and shoot seedling tissues with field parameters at $5 \%$ probability by the $t$ test.

\section{RESULTS}

All variables showed normal distribution of residuals and homogeneity of variances by the Lilliefors and Cochran and Bartlett tests, respectively at $5 \%$ probability. The coefficients of variation resulted in values of $2.8 \%$, $4.3 \%, 8.2 \%, 9.0 \%, 9.7 \%$ and $9.9 \%$ for the lignin content in root tissue, shoot tissue, percentage of seedling survival and increments of height, stem diameter and volume, respectively.

Analysis of variance revealed that frequency of stem swaying applied in $P$. taeda seedlings significantly altered lignin content in above and belowground tissues (Figure 2). Seedlings subjected to 20 swayings resulted in the largest value of lignin content in the roots (Figure 2a) but without difference from the 5 and 10 frequencies. Seedlings subjected to 20 swayings resulted in an 
increase of $7 \%$ on root lignin content compared to the control seedlings.

Increased frequency of stem swaying resulted in an increase of lignin content from aboveground tissues (Figure 2b). The average lignin content of seedlings submitted to frequencies of 20 to 40 swayings did not differ but resulted in a $12.5 \%$ increase in lignin of aboveground tissues.

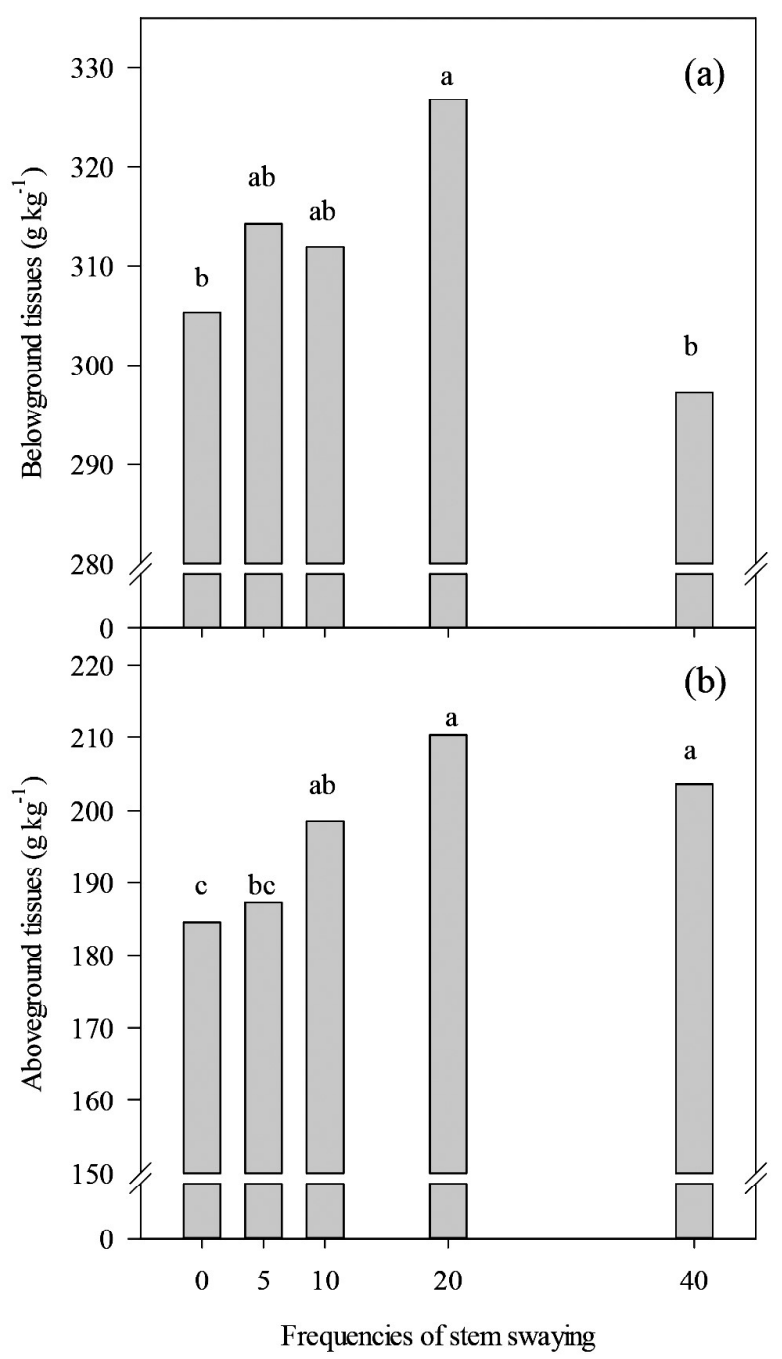

Figure 2 - Lignin content of belowground tissues (a) and of aboveground tissues (b) in $P$. taeda seedlings submitted to daily frequencies of stem swaying for 60 days.

Figura 2 - Teor de lignina no sistema radicular (a) e nos tecidos aéreos (b) em mudas de P. taeda submetidas a diferentes frequências deflexões caulinares diárias por 60 dias.
Results indicated that an increase of stem swaying frequency altered seedling survival and growth rate of outplanted pine seedlings (Figure 3 ). A frequency of up to 20 stem swayings did not result in significant increase in survival (Figure 3a). However with a frequency of 40 swayings survival was reduced to $80 \%$.

Thigmomorphogenesis induced by stem swaying altered seedling stem growth rate (Figure 3 ). The highest average of height (Figure 3b) and stem diameter (Figure 3c) increments were measured in seedlings subjected to frequencies ranging from 10 to 40 swayings, resulting in an average increase of $25 \%$ and $28 \%$, respectively, compared to the control treatment.

Growth rate of stem volume (Figure 3d) from seedlings submitted to 10 and 20 swayings were $72 \%$ higher than that of seedlings from the control treatment. However, it was noted that an increase to 40 swayings reduced seedling diameter growth, which associated with the increase in seedling from the 20 swaying treatment (Figure $3 b$ ) resulted in a lower stem volume growth rate.

There was a significant correlation between seedling survival and lignin content from root tissues (Table 2). Seedling survival increased with the increase of lignin of belowground tissues with a simple correlation coefficient of 0.95. Exclusion of the effect of lignin from aboveground tissues through parcial correlation increased the coefficient to 0.98 showing the little effect that aboveground tissue lignin have upon seedling survival through lignin content from belowground tissues. No significant $(\mathrm{P}>0.05)$ simple or parcial correlation was calculated between lignin of aboveground tissues and seedling survival even with the exclusion of the effect of lignin from belowground tissues.

\section{DISCUSSION}

Thigmomorphogenetic responses resulted in increased lignin content of root system, especially from the ramification root zone in Populus nigra L. seedlings subjected to mechanical stimuli of the taproot (TRUPIANO et al., 2012). This physiological effect enables greater tolerance to mechanical loads caused by winds through anchoring seedling to the soil, and consequently, seedling survival according to data in Table 2 and Figure $3 \mathrm{a}$.

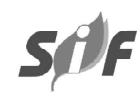

Revista Árvore, Viçosa-MG, v.39, n.5, p.905-913, 2015 

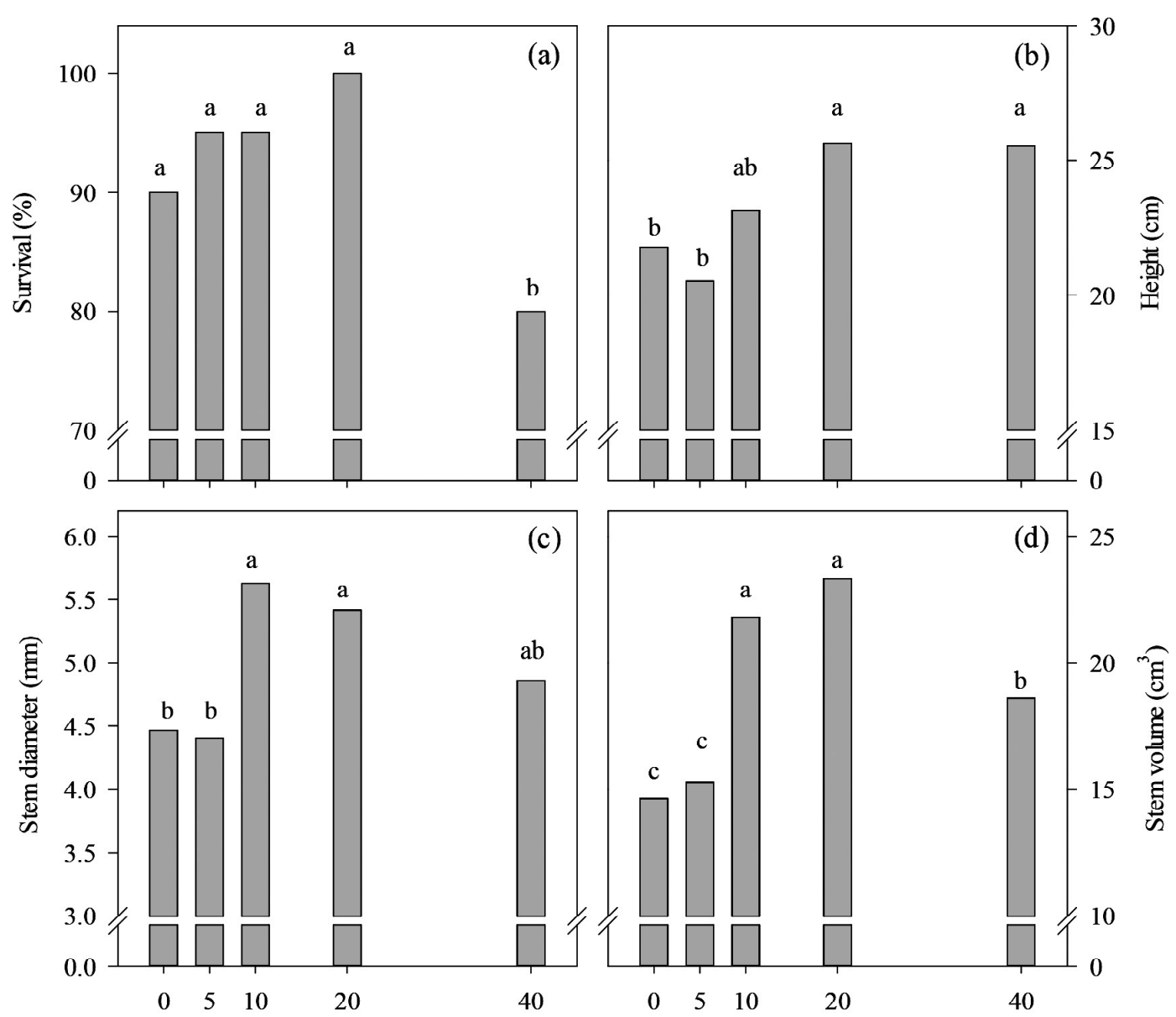

(c)

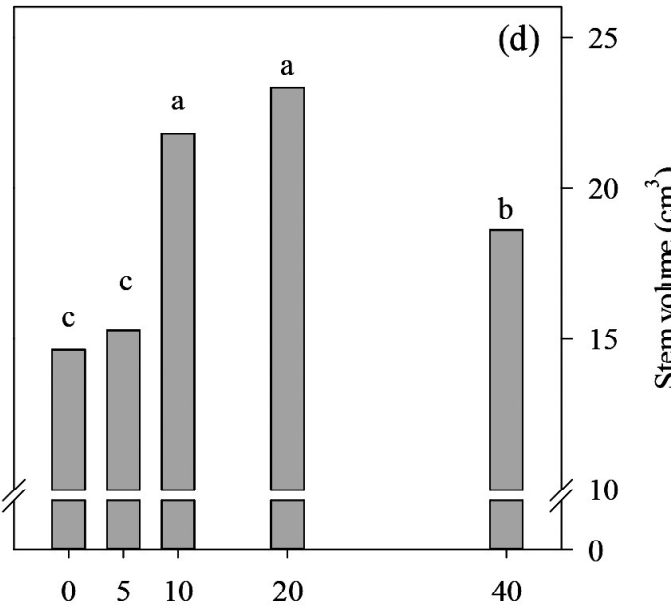

Frequencies of stem swaying

Figure 3 - Survival percentage (a) and increments in height (b) stem diameter (c) and stem volume (d) in P. taeda seedlings submitted to daily frequencies of stem swaying for 60 days.

Figura 3 - Porcentagem de sobrevivência (a) e incrementos em altura (b), diâmetro do coleto (c) e volume do caule (d) em mudas de P. taeda submetidas a diferentes frequências de flexões caulinares diárias por 60 dias.

Table 2 - Simple (R) and partial (r) correlation coefficients between lignin content in bellow and aboveground plant tissues with attributes quantified at 90 days after planting of the $P$. taeda seedlings submitted to daily frequencies of stem swaying for 60 days.

Tabela 2 - Coeficientes de correlação simples $(R)$ e parcial $(r)$ entre os tores de lignina nos tecidos radiculares e aéreos com atributos quantificados aos 90 dias do plantio de mudas de P. taeda submetidas a diferentes frequências de flexões caulinares.

\begin{tabular}{lccccc}
\hline \multirow{2}{*}{ Attributes } & \multicolumn{2}{c}{ Lignin in the below tissues } & & \multicolumn{2}{c}{ Lignin in the above tissues } \\
\cline { 2 - 3 } \cline { 5 - 6 } & $\mathrm{R}$ & $\mathrm{r}($ partial $)$ & & $\mathrm{R}$ & $\mathrm{r}($ partial) \\
\hline Survival & $0.95^{* *}$ & $0.98^{* *}$ & & $0.08^{\mathrm{ns}}$ & $-0.66^{\mathrm{ns}}$ \\
Height & $0.06^{\mathrm{ns}}$ & $-0.72^{\mathrm{ns}}$ & & $0.93^{* *}$ & $0.97^{* *}$ \\
Stem diameter & $0.42^{\mathrm{ns}}$ & $0.27^{\mathrm{ns}}$ & & $0.75^{\mathrm{ns}}$ & $0.72^{\mathrm{ns}}$ \\
Stem volume & $0.54^{\mathrm{ns}}$ & $0.55^{\mathrm{ns}}$ & & $0.88^{* *}$ & $0.89^{* *}$ \\
\hline
\end{tabular}

${ }_{* *, *, \text { ns }}$ Significant to $1 \%, 5 \%$ and not significant by $\mathrm{t}$ test.

Revista Árvore, Viçosa-MG, v.39, n.5, p.905-913, 2015 
Corroborating with the above, Tamasi et al. (2005) reported that more robust and lignified roots from the upper third of the root system of Quercus robur L. seedlings conferred greater resistance to the swinging movement of the shoot and promoted greater anchoring of seedlings with the ground in response to the effects from wind strength. Voelker et al. (2011) reported that a reduction in the survival of Populus spp seedlings hybrid was proportional to the lignin content found in the cell walls of the conducting vessels, thus reducing field survival up to $60 \%$.

Lignin in stems and root cell walls promote greater resistance to embolism, a phenomenon associated with death of woody plants under severe conditions of water deficit and winds capable of raising water pressure in xylem vessels resulting in increased transpiration rate (RETUERTO; WOODWARD, 1993; MARTÍNEZVILALTA; PIÑOL, 2003; KITIN et al., 2010). Therefore, the value of the partial correlation coefficient between lignin content of seedling root system with survival $(\mathrm{r}=0.98)$ can also be associated with the maintenance of hydraulic conductivity in the xylem.

Results from shoot lignin content corroborate with Coleman et al. (2008) who emphasized a parallelism between aboveground lignin content with a reduction of morph and functional shoot quality of Populus alba $\mathrm{X}$ grandidentata hybrid seedlings. With suppression of the gene encoding for the synthesis for coumaril 3 - hydroxylase, the above mentioned authors reported a reduction of height, stem diameter, dry biomass weight and leaf area of seedlings after 140 days of growth under controlled conditions, in addition to producing seedlings with compromised vascular system.

Increase of lignin content in the shoot reduces lodging, stem breaking and loss of connectivity of root system with rhizosphere. The effect of lignin increase was directly associated with growth of $P$. taeda seedlings (Figure $3 \mathrm{~b}$ and $3 \mathrm{~d}$ ) which was significantly correlated with lignin content (Table 2). However, seedling survival was not altered by lignin content similarly to AlvarezClare and Kitajima (2007) results that found no correlation between the survival of eight tropical forest species seedlings and stem lignin content.

The growth rate observed ninety days after planting (Figure 3b, 3c and 3d) may reflect ability and competitive hierarchy of species in the plant community, which may indicate that species behaviour in the absence of competition generates investment in growth and amplifies differences in genetic potential and gains from the change in the growth regime in the nursery, resulting from efforts to achieve the ultimate expression of the propagated genotype (DEL CAMPO et al., 2010; SALVADORI et al., 2013).

In general, outplanted seedling survival was high $(92 \%)$ since there was no competition with weeds and weather conditions were not limiting. In the month prior to planting, the accumulated rainfall was $230 \mathrm{~mm}$, and during the evaluation period the cumulative value was $502 \mathrm{~mm}$, with an air temperature of $20.8 \pm 1.1^{\circ} \mathrm{C}$ and relative humidity of $68.8 \pm 3.7 \%$. However, during the same period wind speed peaked between 62.6 to $85 \mathrm{~km} \mathrm{~h}^{-1}$ (data not shown) with a mean of $16.4 \mathrm{~km} \mathrm{~h}^{-1}$.

The thigmomorphogenetic responses are achieved by generating air flow velocity above $7.9 \mathrm{~km} \mathrm{~h}^{-1}$ or protoplast pressure above $4 \mathrm{mN} \mathrm{m}^{-1}$ which are capable of altering plant growth (TELEWSKI, 2012). Thus, under those conditions, the mechanical stimulus applied in the nursery triggered mechanisms of tolerance to external stimuli, resulting in greater success in establishing $P$. taeda seedlings, as growth at ninety days after planting were strongly influenced by the frequency of swayings applied in the nursery and the wind velocity was on the average higher than that recommended by Telewski (2012).

The results support the hypothesis that lignin content of the seedlings read for planting enhances survival and early growth, corroborating with the above literature on the effects of mechanical stress leading to increased lignification of tissues. In this way, plants with higher lignin content are more likely to establish themselves on the field.

However, morphological, anatomical and biochemical investigations become necessary through histological techniques and lignin staining in order to determine which tissues show changes in concentration and composition in plants subjected to mechanical disturbances.

\section{CONCLUSION}

P. taed $a$ seedlings that are more lignified resulted in greater chance of field establishment, while lignin content of belowground tissues was related to survival and that from aboveground tissues was related to stem growth.

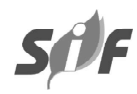

Revista Árvore, Viçosa-MG, v.39, n.5, p.905-913, 2015 


\section{ACKNOWLEDGEMENTS}

We thank Sbaraini Agropecuária S.A. Company for the supply of P. taeda seedlings and CAPES and CNPq for granting scholarships to the authors.

\section{REFERENCES}

ALVAREZ-CLARE, S.; KITAJIMA, K. Physical defence traits enhance seedling survival of neotropical tree species. Functional Ecology, v.21, n.6, p.1044-1054, 2007.

BOERJAN, W.; RALPH, J.; BAUCHER, M. Lignin biosynthesis. Annual Review of Plant Biology, v.54, p.519-546, 2003.

CLOSE, D.C.; BEDLE, C.L.; BROWN, P.H. The physiological basis of containerised tree seedling 'transplant shock': a review. Australian Forestry, v.68, n.2, p.112-120, 2005.

COLEMAN, H. D.; SAMUELS, A. L.; GUY, R. D.; MANSFIELD, S. D. Perturbed lignification impacts tree growth in hybrid poplar - A function of sink strength, vascular integrity, and photosynthetic assimilation. Plant Physiology, v. 148, n. 3, p. 1229-1237, 2008.

CORDERO, R.A. Ecophysiology of Cecropia schreberiana saplings in two wind regimes in an elfin cloud forest: growth, gas exchange, architecture and stem biomechanics. Tree Physiology, v.19, n.3, p.153-163, 1999.

COUTAND, C.; CHEVOLOT, M.; LACOINTE, A.; ROWE, N.; SCOTTI, I. Mechanosensing of stem bending and its interspecific variability in five neotropical rainforest species. Annals of Botany, v. 105, n. 2, p. 341-347, 2010.

DAVIS, A.S.; JACOBS, D.F. Quantifying root system quality of nursery seedlings and relationship to outplanting performance. New Forests, v.30, n.2-3, p.295-311, 2005.

DEL CAMPO, A.D.; NAVARRO, R.M.; CEACERO, C.J. Seedling quality and field performance of commercial stocklots of containerized holm oak (Quercus ilex) in Mediterranean Spain: an approach for establishing a quality standard. New Forests, v.39, n.1, p.19-37, 2010.
EMPRESA BRASILEIRA DE PESQUISA AGROPECUÁRIA - EMBRAPA. Centro Nacional de Pesquisa de Solos. Sistema brasileiro de classificação de solos. 2.ed. Rio de Janeiro: Embrapa, 2006. 306p.

FINGER, C.A.G. Fundamentos de biometria florestal. Santa Maria: UFSM/ CEPEF/FATEC, 1992. 269p.

GROSSNICKLE, S.C. Why seedlings survive: influence of plant attributes. New Forests, v.43, n.5-6, p.711-738, 2012.

HAMANN, T.; BENNETT, M.; MANSFIELD, J.; SOMERVILLE, C. Identification of cell-wall stress as a hexose-dependent and osmosensitive regulator of plant responses. The Plant Journal, v. 57, n. 6, p. 1015-1026, 2009.

JAFFE, M.J. Thigmomorphogenesis: the response of plant growth and development to mechanical stimulation with special reference to Bryonia dioica. Planta, v.114, n.2, p.143-156, 1973.

KERN, K. A.; EWERS, F. W.; TELEWSKI, F. W.; KOEHLER, L. Mechanical perturbation affects conductivity, mechanical properties and aboveground biomass of hybrid poplars. Tree Physiology, v. 25, n. 10, p. 1243-1251, 2005.

KITIN, P.; VOELKER, S. L.; MEINZER, F. C.; BEECKMAN, H.; STRAUSS, S. H.; LACHENBRUCH, B. Tyloses and phenolic deposits in xylem vessels impede water transport in low-lignin transgenic poplars: a study by cryofluorescence microscopy. Plant Physiology, v. 154 , n. 2, p. $887-898,2010$

MARJAMAA, K.; KUKKOLA, E.M.; FAGERSTEDT, $\mathrm{K}$.V. The role of xylem class III peroxidases in lignification. Journal of Experimental Botany, v.60, n.2, p.367-376, 2009.

MARTÍNEZ-VILALTA, J.; PIÑOL, J. Limitaciones hidráulicas al aporte de agua a las hojas y resistencia a la sequía. Ecosistemas, v.7, n.1, p.1-7, 2003

MEDEIROS NETO, P. N.; OLIVEIRA, E.; CALEGARI, L.; ALMEIDA, A. M. C.; PIMENTA, A. S.; CARNEIRO, A. C. O. Características físicoquímicas e energéticas de duas espécies de 
ocorrência no semiárido brasileiro. Ciência Florestal, v. 22, n. 3, p. 579-588, 2012.

MONTEIRO, M.B.O.; PEREIRA, R.P.W.; ABREU, H.S. Bioquímica da lignificação de células xilemáticas. Floresta e Ambiente, v.11, n.2, p.48-57, 2004.

PELTIER, A.J.; HATFIELD, R.D.; GRAU, C.R. Soybean stem lignin concentration relates to resistance to Sclerotinia sclerotiorum. Plant Disease, v.93, n.2, p.149-154, 2009.

PEREIRA, R. P. W.; ABREU, H. S.; MONTEIRO, M. B. O.; SOUZA, N. D. Variação ligno-anatômica em mudas de Eucalyptus grandis (Hill ex Maiden) tratadas com reguladores de crescimento. Cerne, v. 17, n. 3, p. 369-375, 2011.

PETER, G. F.; WHITE, D. E.; DE LA TORRE, R.; SINGH, R.; NEWMAN, D. The value of forest biotechnology: a cost modelling study with loblolly pine and kraft linerboard in the southeastern USA. International Journal of Biotechnology, v. 9, n. 5, p. 415-435, 2007.

PILATE, G.; DEJARDIN, A.; PEPLE, J.C. Field trials with lignin-modified transgenic trees. In: JOUANIN, L.; LAPIERRE, C. (Ed.). Lignin: biosynthesis, biodegradation and bioengineering. London: Academic Press, 2012. p.2-37.

RAMOS, P.; LE PROVOST, G.; GANTZ, C.; PLOMION, C.; HERRERA, H. Transcriptional analysis of differentially expressed genes in response to stem inclination in young seedlings of pine. Plant Biology, v. 14, n. 6, p. 923-933, 2012.

RETUERTO, R.; WOODWARD, F.I. The influences of increased $\mathrm{CO} 2$ and water supply on growth, biomass allocation and water use efficiency of Sinapis alba L. grown under different wind speeds. Oecologia, v.94, n.3, p.415-427, 1993.

ROWELL, R. M. Chemical modification of wood: a short review. Wood Material Science and Engineering, v. 1, n. 1, p. 29-33, 2006.

SAIDI, I.; DJEBALI, W.; NAIJA, S.; BOUZID, S.; AMMAR, S. Change in antioxidant and lignifying enzyme activities in rubbing tomato (Solanum lycopersicum) internodes. African Journal of Biotechnology, v. 26, n. 10, p. 5193-5202, 2011.

SALVADORI, S. L.; DUARTE, C. U. N. B. D.; SILVA, A. F. G.; KLEIN, W. L. Análise de sobrevivência e crescimento de Cordia trichotoma, Boraginaceae, Lamiales, no sul de Mato Grosso do Sul - Brasil. Ciência Florestal, v. 23, n. 4, p. 735-742, 2013.

SIGMA PLOT. Scientific Graphing Software: Versão 12.0. San Rafael: Jandel Corporation, 2011.

TAMASI, E.; STOKES, A.; LASSERRE, B.; DANJON, F.; BERTHIER, S.; FOURCAUD, T.; CHIATANTE, D. Influence of wind loading on root system development and architecture in oak (Quercus robur L.) seedlings. Trees, v. 19, n. 4, p. 374-384, 2005.

TELEWSKI, F. W. Is windswept tree growth negative thigmotropism? Plant Science, v. 184, p. $20-28,2012$

TELEWSKI, F.W.; PRUYN, M.L.

Thigmomorphogenesis: a dose response to flexing in Ulmus americana seedlings. Tree

Physiology, v. 18, n.1, p.65-68, 1998

TRUPIANO, D.; DI IORIO, A.; MONTAGNOLI, A.; LASSERRE, B.; ROCCO, M.; GROSSO, A.; SCALONI, A.; MARRA, M.; CHIATANTE, D.; SCIPPA, G. S. Involvement of lignin and hormones in the response of woody poplar taproots to mechanical stress. Physiologia Plantarum, v. 146, n. 1, p. $39-52,2012$.

van SOEST, P. J. Nutritional ecology of the ruminant. 2.ed. Ithaca: Cornell University Press, 1994. 476p.

VOELKER, S. L.; LACHENBRUCH, B.; MEINZER, F. C.; KITIN, P.; STRAUSS, S. H. Transgenic poplars with reduced lignin show impaired xylem conductivity, growth efficiency and survival. Plant, Cell and Environment, v. 34, n. 4, p. $655-668,2011$.

VOLKWEIS, C. R.; DRANSKI, J. A. L.; ORO, P.; MALAVASI, U. C.; MALAVASI, M. M. Efeito da tigmomorfogênese na morfometria de mudas de Maytenus ilicifolia (Schrad.) Planch. Ciência Florestal, v. 24, n. 2, p. 339-342, 2014.

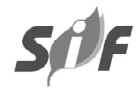

Revista Árvore, Viçosa-MG, v.39, n.5, p.905-913, 2015 